\title{
BIOCHEMICAL FEATURES Of IRAQI PATIENTS INFECTED WITH HEPATITIS E VIRUS COMPARED WITH THOSE INFECTED WITH HEPATITIS A VIRUS
}

\section{Elham.F. AL.Fakhri \\ Department of clinical analysis, College of Pharmacy, Baghdad University, Baghdad-Iraq}

Received: 09.04.2001

Accepted: 11.06.2002

\section{ABSTRACT :}

This study was designed to compare the effect of two types of viral hepatitis A and E (HAV and HEV) on liver functions in Iraqi individuals by the measurement of biochemical changes associated with hepatitis.

The study performed on $58 \mathrm{HEV}$ and $66 \mathrm{HAV}$ infected patients compared with 28 healthy subjects. The measured biochemical tests include total serum bilirubin, serum transminases (ALT and AST) alkaline phosphatase (ALP) and gamma glutamyl transferase (GGT).

The study showed that adolescent and young adults (17-29) years, were mostly affected by HEV while children (5-12) years were frequently affected by HAV. The severity of liver damage in HEV patients was higher than HAV patients as a result of high serum transaminase levels.

Patients with HEV were associated with cholestasis due to high serum level of ALP and GGT compared to HAV patients.

الخـلاصـة.

الهدف من هذه الدراسة هي المقارنة بين تأثير التهاب الكبد الفايروسي الحاد نوع Aو التهاب الكبد الفايروسي الحساد

نوع Eلى وظائف الكبد للمرضى العر اقيين وذلك بأجر اء الفحوص المختبرية التي لها علاقة بهذين المرضين وقد شملت الدراسة

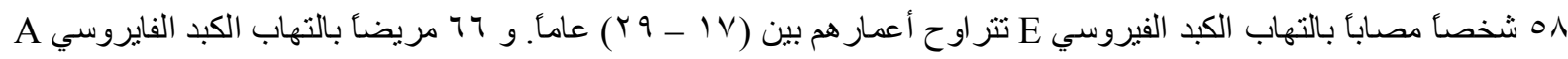
تتر اوح أعمار هم بين (0 - r l) عامأ، مقارنة مع ^^ شخصا من الأصحاء. الفحوص المختبرية شملت Bilirubin و الأنزيمـات: Alkaline phosphates Gamma Glutamy Transferase (GGT) , ((ALT \& AST) Transaminases) A هم من الأطفال بينما المرضى المصابين بنوع E هم من الثباب (ALP) , الدر اسة بينت أن معظم المرضى المصابين بنوع (A) , و اليافعين. وكذلك اتضح من سير الدر اسة أن شدة المرض في التهاب الكبد الفايروسيE هي أعلى منها في نمط A وذلك للزيادة الحاصلة في نسبة المادة الصفر اءونسبة الأنزيمات (ALT\&AST) التي تحررت من خلايا الكبد التالفة. أيضـا الدراسـة بينت أن التهاب الكبد الفايروسيE سبب في ركود الصفراء وقلة إفر ازها بينما لم تظهر هذه الحالة عند الأطفال المصسابين بالتهاب الكبد الفايروسي A (1) (n) 


\section{INTRODUCTION: -}

\section{Hepatitis E virus}

Hepatitis E virus (HEV) is an acute, icteric self-limiting disease, which is spread widely in many tropical and subtropical countries, where it occurs both in the form of epidemic of variable magnitude or sporadically ${ }^{(1)}$.

Hepatitis E virus is a small RNA virus which is temporally classified as a member of calcivirus family.

Transmission is via faecal — oral routes but the possibility of blood transmission has been raised concerning anti -HEV prevalence among chronic hemodialysis patients are give conflicting results $^{(2)}$, also vertical transmission from mother to fetus can be observed ${ }^{(3)}$, Hepatitis E is not clinically differs from other acute viral hepatitis.

The course of the disease is usually benign with little risk of development of chronic symptom and cirrhosis ${ }^{(4)}$. High incidences of sever cases with $1-2 \%$ mortality ${ }^{(5)}$.

Acute liver failure secondary to hepatitis $\mathrm{E}$ infection is common in pregnancy and associated with mortality rate up to $20 \%{ }^{(6)}$ because both in women and her fetus are at risk, escalated production of progesterone during pregnancy leads to downregulation of cellular (cell mediated) immune function. The role of long persisting HEV antibodies in humans was investigated ${ }^{(7)}$ candidate vaccines have not yet reached clinical trials ${ }^{(\mathbf{8})}$.

\section{$\underline{\text { Hepatitis A virus }}$}

Hepatitis A virus (HAV) a counts for $20-25 \%$ of hepatitis cases worldwide. It- is caused by RNA picorna virus ${ }^{(9)}$. The virus mediates injury by both cellular and non cellular immune mechanisms an IgM antibody (anti HAV IgM) appears early in the course of illness and persist 2-6 months and IgG antibody, appears towards the end of acute illness presist for several years and conveys lifelong immunity, Hepatitis A occurs in sporadics and epidemic forms with incubation period of 15-50 days Epidemic have been associated with water borne and food borne countries, outbreak have occurred through infected food handlers in restaurants. The clinical course of acute hepatitis $\mathrm{A}$ is usually that of a mild flulike illness that last for a few days to a few weeks, only $10 \%$ become jaundiced. The disease is more prolonged and serious in persons over 50 years old. Hepatitis A infection does not cause chronic carrier state ${ }^{(\mathbf{1 0})}$ and perinatal transmission is extremely uncommon, but cholestasis manifested by several weeks of jaundice and pruritis may occur in adults.

Hepatitis A can be prevented by immunization with an inactivated vaccine which highly effective ${ }^{(11)}$ 


\section{SUBJECTS AND METHODS:}

Venous blood samples were obtained from 58 patients with acute hepatitis E virus (HEV) aged (17 - 29) years (22 females, 36 males) screened in central public Health Lab. (Virology Dept). by linked immunosorbent assay [ELISA] Bioelisa (HEV) IgM .[(Biokit S.A) (Barcelona ,Spain)] Also venous blood Samples were collected from 66 patients with acute hepatitis A virus (HAV) (26 Females, 40 males) aged (5 - 12 ) years screened in Central public Health laboratory (viralogy Dept) by microelisa system, Hepanostika HAV. IgM (Organon, teknika GmbH).

Blood samples withindrawn from 28 healthy individuals aged (5-25) years (12 females. 16 males) Served as control.

All sera were examined for liver function tests including total serum bilirubin (Bilirubni kit. Randox) ${ }^{(12)}$ Alanine .Aspartate transaminases kits Randox. England) ${ }^{(13)}$

Alkaline phosphatase (ALP) phosphates alkaline kit (biomerieux S.a France) ${ }^{(14)}$ And Gamma glutamyl transferase (GGI) Enzylin kit (biomerieux France) ${ }^{(15) .}$

\section{RESULTS:}

The results of this study obtained are found in table I.II, III.

Table I shows that the ages of patients infected with hepatitis E virus were $(19.22 \pm 1.48)$ years old while those with hepatitis A were $(7.76 \pm 1.05)$ years old.

\begin{tabular}{|l|l|l|l|}
\hline Age (years) & HEV & HAV & Controls \\
\hline Mean & 19.22 & 7.76 & 15.52 \\
+SEM & \pm 1.48 & \pm 1.05 & \pm 2.44 \\
\hline
\end{tabular}

\section{Table I}

Table II shows that all the patients of both groups were icteric but the level of total serum bilirubin of patients with hepatitis $\mathrm{E}$ virus were insignificantly higher than those with HAV (t $=1.388 . \mathrm{p}<0.05)($ Fig. $(1))$

\begin{tabular}{|l|lr|lr|lr|}
\hline Parmeters & HEV & & HAV & \multicolumn{2}{|l|}{ Controls } & \\
\hline T.S. Bilirubin & 5.578 & & 3.57 & & 0.74 & \\
mg/dL & \pm 1.238 & & \pm 0.766 & & \pm 0.23 & \\
\hline Alanine & & 63.84 & & 41.42 & & 10.4 \\
Transaminase & & $4.510 \pm$ & & $3.390 \pm$ & & $5.43 \pm$ \\
I.U/L & & & & & & \\
\hline Aspartate & & 68.76 & & 48.611 & & 9.3 \\
Transaminase & & $4.246 \pm$ & & $1.457 \pm$ & & $4.2 \pm$ \\
IU/L & & & & & & \\
\hline
\end{tabular}

Table II

Note:

Normal range for T.S. bilirubin $=0.2-1 \mathrm{mg} / \mathrm{dL}$

Normal range for Alanine transaminase $=2-12 \quad 1 . \mathrm{U} / \mathrm{L}$

Normal range for Aspartate transarninase $=2-12 \quad 1 . \mathrm{U} / \mathrm{L}$ 


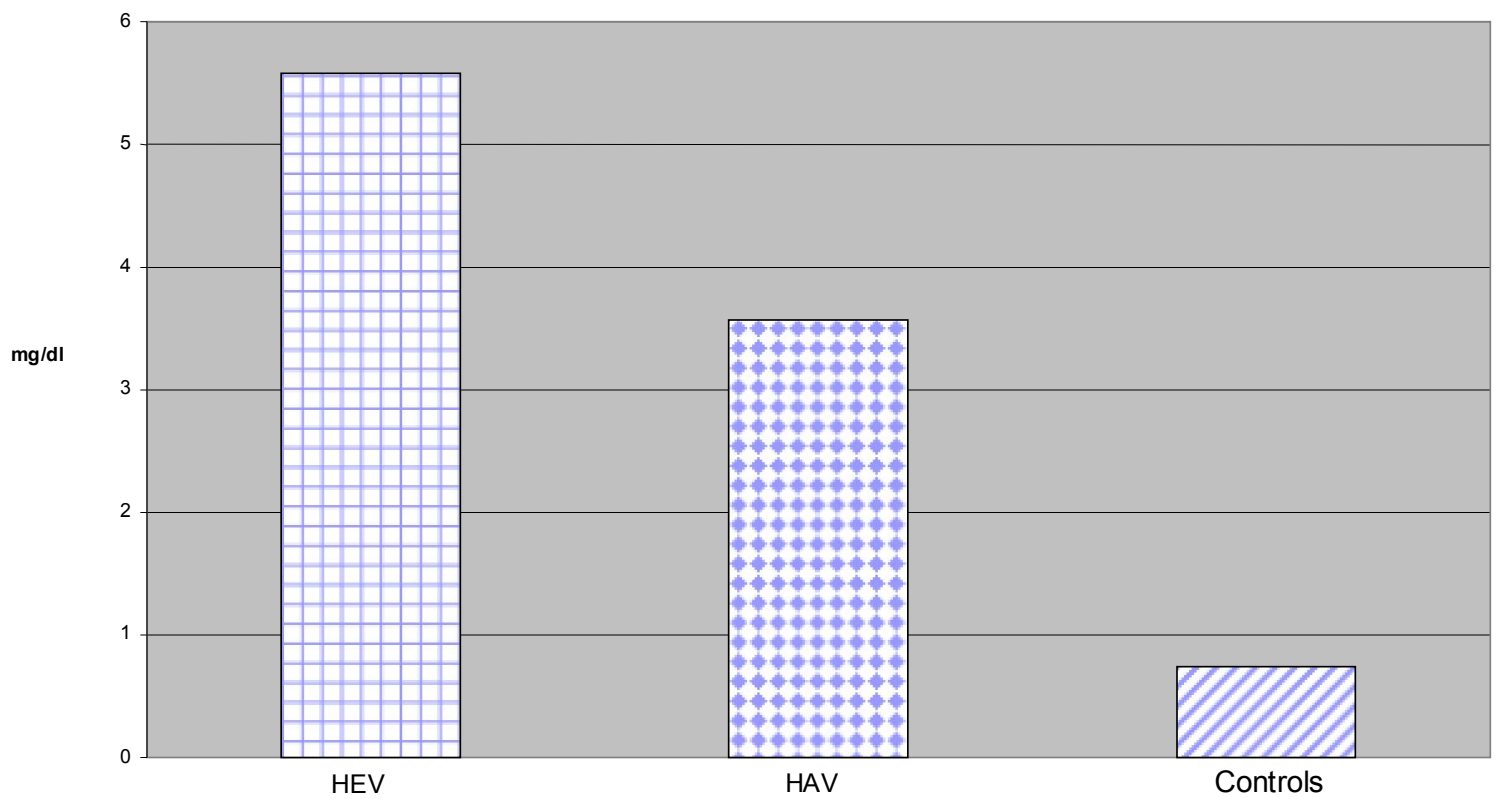

Fig.1 - Total Serum Bilirubin

The concentration of serum transaminases enzymes (Alanine and Aspartate transaminases) of patients with hepatitis A shows moderate to high elevation while that of HEV were significantly higher $(\mathrm{t}=4.048 \mathrm{P}>0.05)$ for ALT and those for AST ( $\mathrm{t}=3.28 \mathrm{P}>0.05)$ (Table II) (Fig.(2)).

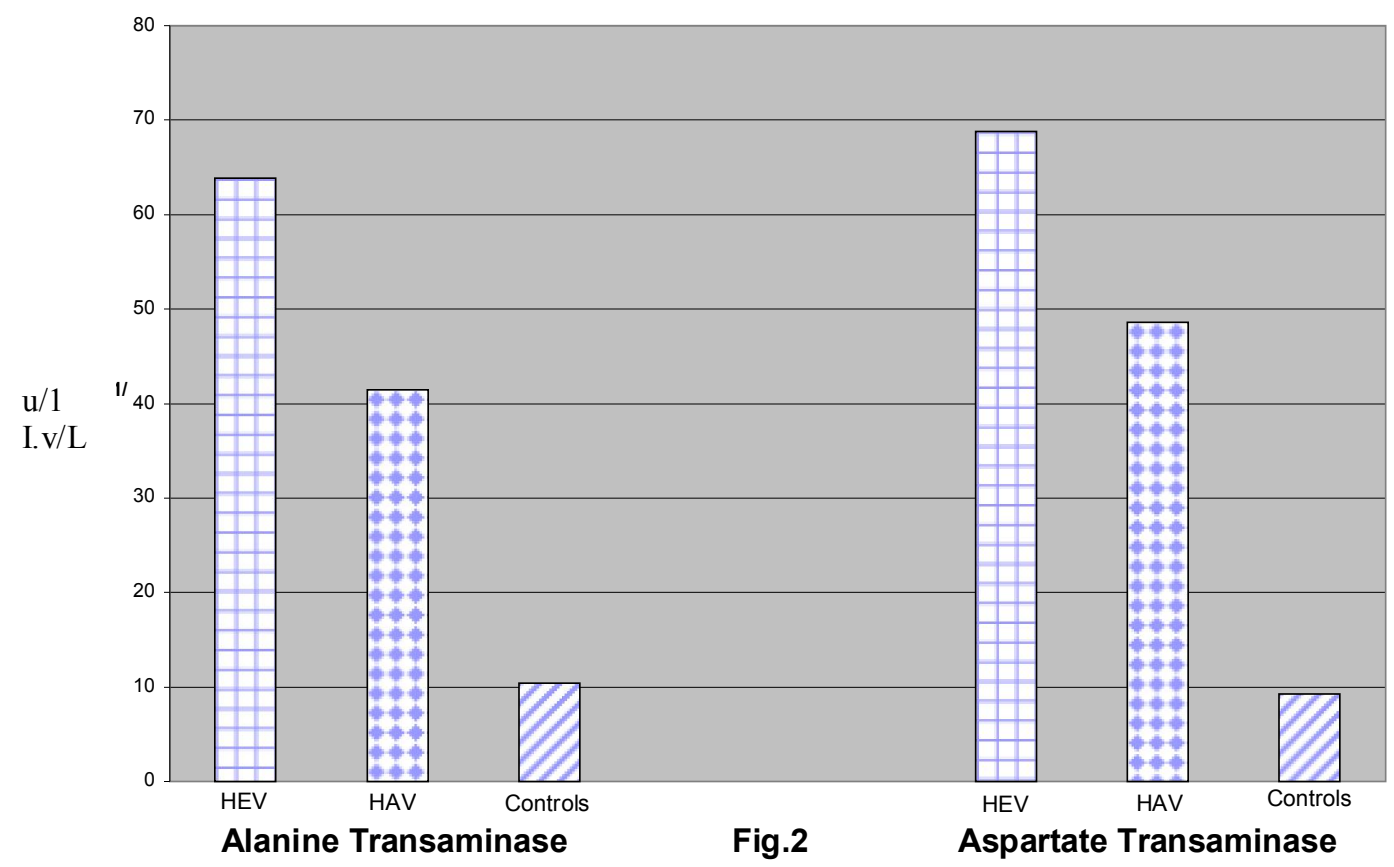

Serum alkaline phosphatase (ALP) enzymeof HAV infected subjects were mostly within normal 
range but the concentration of serum

ALP with hepatitis HEV were significantly high ( $\mathrm{t}=3.62 \mathrm{P}>0.05)$ (Fig.(3)).

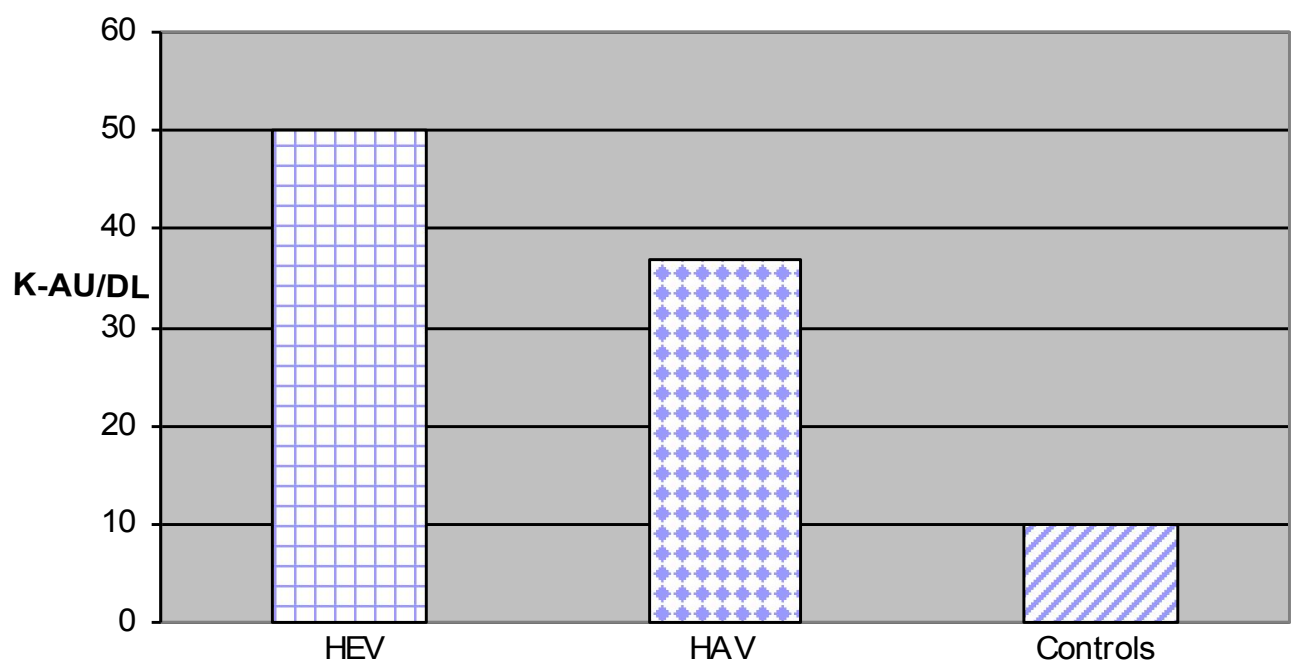

Fig 3. Serum Alkaline Phosphatase

The level of serum glutamyl transferase enzyme (GGT) with

hepatitis A virus were within normal range while those with HEV were Significantly high $(t=4.796 p>0.05)$ Table III. (Fig. (4)).

\begin{tabular}{|l|l|l|l|}
\hline Parmeters & HEV & HAV & Controls \\
\hline $\begin{array}{l}\text { Alkaline } \\
\text { Phosphatase }\end{array}$ & 50.826 & 36.32 & 10.132 \\
K-AU/dL & \pm 7.529 & \pm 8.56 & \pm 3.425 \\
\hline $\begin{array}{l}\text { Gamma glutamyl } \\
\text { Transferase }\end{array}$ & 41.35 & 10.21 & 12.918 \\
U/L & \pm 4.748 & \pm 2.64 & \pm 2.202 \\
\hline
\end{tabular}

\section{Table III}

Note:

Normal range for alkaline phosphatase (adult) $=3-13 \mathrm{~K} . \mathrm{AU} / \mathrm{d} 1$

Normal range for alkaline phosphatase (children) up to $20 \mathrm{~K}$.AU/dl

Normal range for, glutamyl transferase at $25^{\circ}$ are:

$$
\begin{aligned}
\text { Men } & =6-24 \mathrm{DL} \\
\text { Wormen } & =5-21 \mathrm{U} / \mathrm{L}
\end{aligned}
$$




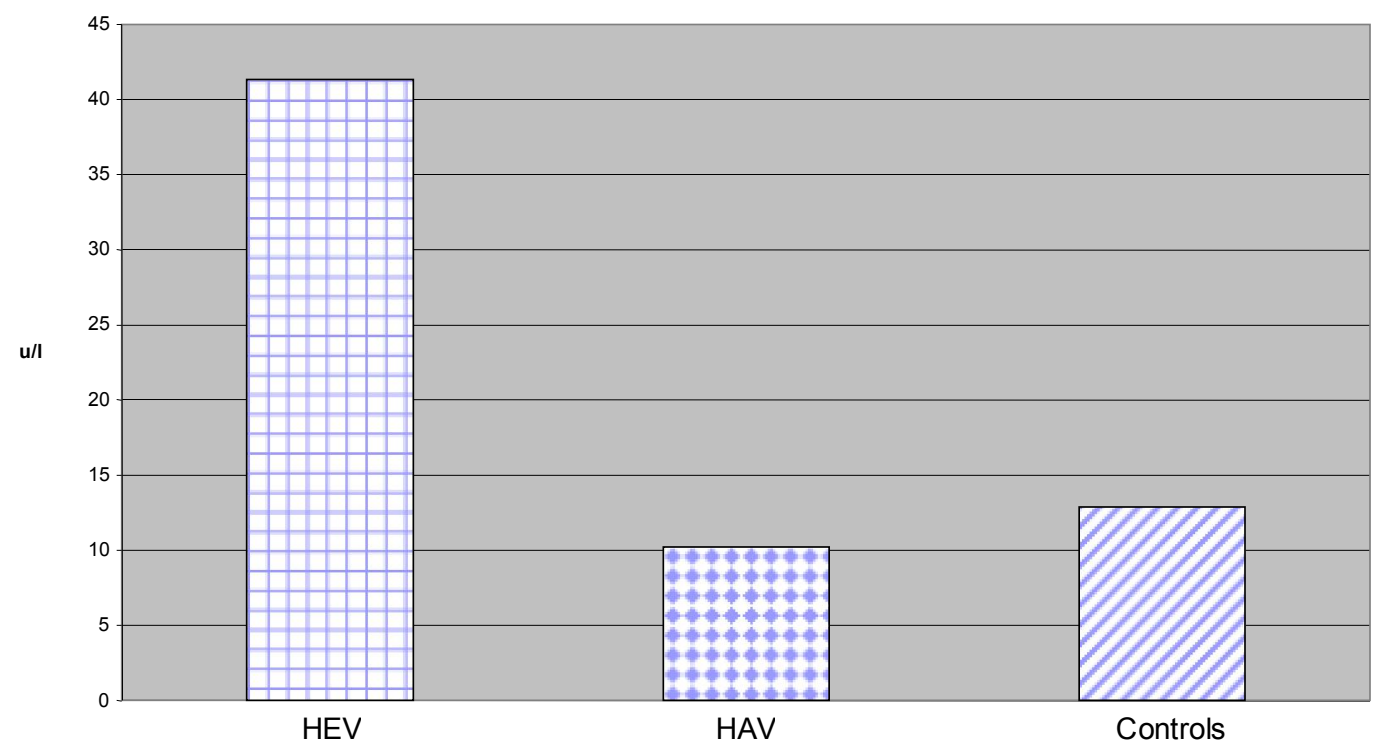

Fig.4 - Serum Gamma Glutamyl Tranferase

\section{DISCUSSION:}

The results on table I proves that the patients with hepatitis E virus were Frequently adolescents and young adults while that with hepatitis A virus were mostly children ,this has been documented in other studies ${ }^{(\mathbf{1 6}, \mathbf{1 7})}$.

The results of liver function tests for (HEV) and (HAV) of infected patients shows that all patients of both groups were icteric but the total serum bilirubin of HEV group were insignificantly higher than that of HAV group (table II)

Serum alanine and aspartate transaminase concentration are highly sensitive indicatores of hepatocelluler damage. They provide a qualitative assessment of the degree of damage sustained by the liver. From the above results the severity of acute HEV more than that of HAV due to high levels of aminotransferase enzymes in HEV patients that leads to hepatocytes damage in those patients In most patients with HEV.

Resolution of hyperbilirubinemia and abnormal serum ALT occurs within 3 weeks (range 1-6 weeks) and there is no clinical and histological evidence of chronic hepatitis

Alkaline phosphatase level is obtained primarily to assess the degree of cholestiasis present in the liver. The enzyme associated with the microvilli of bile canaliculi with sinusoidal membrane present in the cytosol. Gamma glutamyl transferase (GGT) has been identified in the same membrane as alkaline phosphatase it is useful to measure the GGT level to confirm the hepatic origin of an elevated level ${ }^{(19)}$

The high level of ALP and GGT with bilirubin of HEV patients indicate that the HEV in Iraqi patients associated with marked intrahepatic cholestasis ${ }^{(\mathbf{2 0})}$ while the normal level of GGT and 
slight elevation of ALP of infected patients with hepatitis A virus not associated with cholistasis although there was other study proved that acute HAV associated with chalestasis in adults \& adolescent) ${ }^{(18)}$. This may be depend on the age of infected patient. or count on the geographic factor $\&$ the environment of the virus exist. ${ }^{(21)}$

\section{CONCLUSIONS:}

From the results and discussion of this study we conclude that:

1- HEV frequently affect adolescents and young adults while HAV seroprevalance in children.

2- The severity of HEV disease is significantly higher that of HAV disease (liver damage)

3- Acute hepatitis E virus associated with marked cholestasis while that of acute hepatitis A virus did not.

\section{REFERENCES:}

1- Balyan M.S (Epidemiology of hepatitis E virus infection). J. viral -Hepat 1997 May 4 (3) 155-65.

2- Fabrizi F; Lunghi G; Bacchini G; Corti M; Pagano A; Locatelli F. (Hepatitis E virus infection in hemodialysis patients) Nephrol - Dial transplant 1997 Jan 12:133-6.

3- Aggarwal R; Naik S.R (Hepatitis E and intrafamilial transmission) indian J - Gastroe 2000 Jan - March 19 (1): 6-8

4- Balistrevi WF ( viral hepatitis E ) Med clin north Am 1991 .9: 365-399.

5- Wang C.H ; Tschen S.Y ( Hepatitis E virus and primary billiary cirrhosis ) QJM 1997 Feb: 90 (2) : 154-55.

6- Hussaini SH; Skidmore SJ; Richardson P; Sherratt LM; Cooper BT; Grady JG. ( Sever Hepatitis E infection during pregnancy) J.Mral hepat 1997 Jan 4(4) 51-4.

7- Cauhan A; Dilawari JB; Sharma R; Mukesh M; Saroa SR.( Role of long - presisting human hepatitis E virus antibodies in protection) Vaccine 1998 Apr; 16(7).755-6.

8- Harrison T.J. (Hepatitis E virus .... An update) 1999 Jun 19(3):71-176.

9- Feinston S.M. (Hepatitis a detection by immune electrone microscopy of a virus-like antigen associated with acute illness) science 1973; 182:1026-1028

10- Duff p: (Hepatitis in pregnancy): semin perinatal 1998 Aug;22(4)277-283.

11 - Innis B.L. Snitblan R.E. (Protection against hepatitis A by inactivated) JAMA, 1994: 13281334.

12- Lath GH,Ruthven CR J.ClinPath 1958; 11.155.

13 - Bergmeyer HU (Editor of enzymatic analysis) 1974 ; Vol ${ }_{2}^{\text {nd }}$ English edition , verlage chemic weinheim , academic press London, New York.

14- Kind P.R.N and king E.J Clin Path 1974; 7:322.

15- Persijn J.P Clin. Chim Acta $1971 ; 35$ : 239-240. 
16- Arora AK; Nanda SK; Ansari IH; Joshi S; Dixit R; Bathla R. (Hepatitis E infection in children J.Gastroentro - hepato 1999 Jun: 14(6)572-7.

17- Alvarez Munoz. MT; Torres J; Damasio L; Gomez A; Tapia Conyer R; Munoz O.(Seroepidemiology of hepatitis E virus infection in Mexican subjects 1-29 years of age)

18- Arch - Med. Res 1999 May-Jun; 30(3);251-4.

18- Nicocali Naoumov (Heptitis A and E) Medicine 1999; The medicine publishing company. 19- N.Field (Editor of Virology) 1985 chapter 61 page1426, Raven press, New York

20-Shorder 0; Lee JH; Herrmann G; Rabenau H; Zeuzem S.(Sever acute cholestatic viral hepatitis E in non pregnant women) Dtsch - Med -Wochen Sehr 1997 Jan 3;122(1-2) :21-24.

21- Simmonds P. (variability of hepatitis E virus) Hepatology 1994;21;1 144-1151. 